\title{
University News / Nouvelles des Universités
}

\section{TORONTO}

Ontario Graduate Scholarships in Science and Technology (OGSST) in the Faculty of Forestry at the University of Toronto

Last year, the University of Toronto participated in a new matching program announced by the Government of Ontario. This program, called the Ontario Graduate Scholarships in Science and Technology (OGSST), was designed to reward the excellence and achievements of graduate students across Canada in the fields of science and technology. A contribution of $\$ 50000$ made by December 31,1999 by a private sector donor was matched once by the University of Toronto to create a total permanent endowment of $\$ 100000$. This endowment will generate an income of $\$ 5000$ to fund the award. Subsequently, this $\$ 5000$ will be double matched by the Government of Ontario every year until 2008, adding another $\$ 10000$ so that the total amount received by the student is $\$ 15000$. After 2008, the University will continue in perpetuity the annual $\$ 10000$ augmentation of the payout of the award.

The Faculty of Forestry was fortunate to secure donations from Alpa Lumber Inc., Network Forest Products Limited and Tom and Phyllis Buell, whose generosity made possible the creation of three scholarships, which will be awarded, to forestry graduate students in perpetuity.

\section{CONFOR 2000 Conference}

CONFOR 2000, the 16th conference for graduate students in forestry and environmental sciences, was recently held at the Faculty of Forestry, University of Toronto. This conference is unique in that it is organized and run by students and is an invaluable opportunity to present their research in front of their peers. For many, it is also one of the first opportunities to present in a conference setting and allows for the exchange of ideas with students with similar interests. This year, between February 3rd and February 6th, 49 students took part in this annual conference with poster displays and presentations. Participants came from the University of Toronto, Université Laval, University of New Brunswick, University of Maine, State University of New York and Stephen F.
Austin State University (Texas). As always, the posters and presentations were only one part of the conference program: There were four guest speakers presenting their views and key issues in forestry covering the following fields, Dr. Paul Cooper on wood science, Dr. David Balsillie on policy, Fred Pinto on silviculture and Dr. Andy Kenny on urban forestry. To reflect the changing nature of the people involved in the forestry community, a reception was held on "Diversity in Forestry," encompassing all forms of diversity including cultural, racial, linguistic and sexual diversity. Following was a first for a science conference, a "Queer Night Out," where all conference participants took part in dinner, dessert and dancing in Toronto's gay village. Dr. Peter Schleifenbaum, from the Haliburton Forest and Wildlife Reserve Ltd. was the keynote speaker and before the closing banquet reiterated that there is more than just trees to a forest. This year's conference was a great success and the University of Toronto's organizing committee looks forward to next year's conference in Nacodoches Texas.

\section{Recent Publications}

L. R. Rajasekaran and T.J. Blake 1999. New plan growth regulators protect photosynthesis and enhance growth under drought of jack pine seedlings. Journal of Plant Growth Regulation 18: 175-181.

\section{Conference Presentations}

Andrew Park, PhD candidate, presented the following two papers on November 24-26 1999, at the 4th Mexican Congress on Forest Resources and their Sustainable Management, Durango, Mexico.

"Environmental Relations of Post Harvest Natural Regeneration in Pine-Oak Forests of the Sierra Madre Occidental, Durango, Mexico" and as part of a special panel presentation on the importance of forest fire to pine-oak ecosystems. Andrew's talk was entitled, "Natural regeneration under different surface fire regimes in pine-oak forests of the Sierra Madre Occidental: preliminary results."

Amalia Veneziano
NEW BRUNSWICK

\section{CIF Essay by Seth Caine}

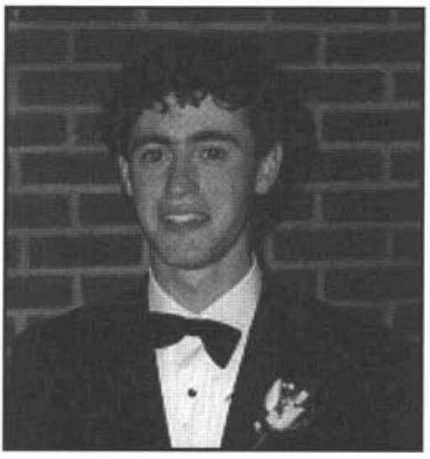

This fall I was fortunate to be able to attend the Annual Meeting of CIF/IFC in beautiful Banff, Alberta. I was able to do this through the generous support of the Faculty of Forestry at UNB and the Maritime Section of the CIF/IFC. The theme of the conference was "Back to the Future in 100 Years," and the organizers must be congratulated on an extremely well run and informative conference. Speaking as a young Canadian, first I would like to thank UNB and CIF/IFC for the opportunity to see more of my country. I have never had the opportunity to see Rockies and even as I write this now I feel awed by their beauty. It was also wonderful to experience the warmth of western hospitality.

In my case the conference taught me a lot on the conceptions that exist about forestry, both the ideas of foresters and the ideas of society. Two particular sessions stood out to me in this regard. They were entitled "At 2000's Doorstep - Where are we now?" and "Into the 21st Century - Where are we going?" Both of these sessions provided a lot of insight as to how Canadian Forestry sees itself. In the "At 2000's Doorstep - Where are we now?' session, a group of very distinguished and well spoken forestry individuals spoke on how they saw Canadian Forestry; afterwards, four speakers were asked to reply to the earlier lectures. These four speakers all represented different groups within society that are directly concerned with forestry, including an Aboriginal representative, a mayor of a forest industry based town, an investment manager, and an applied sociologist. The Aboriginal representative shared with us the successes that her community has expe- 
rienced. This particular community has embarked on a forest-based economic improvement plan that in agreement with industry sees their community play an a integral role in managing and harvesting their lands. This has lead to many positive social spin-offs including higher standards of living and higher levels of education. The mayor very effectively put a human face to the discussions. He talked about children and families in his community and how their well-being depended on forestry. $\mathrm{He}$ talked about what forest industry owed people and how he felt these social and economic issues could best be addressed. The economist was the barer of doom and gloom. His message was that forestbased industry is not performing as it must and that if it doesn't it will play less and less of a prominent role in Canada's economy. His comparisons were hard to argue with. The sociologist emphasized the need of a positive public image for forestry. He encouraged companies to educate and communicate with the public. He pointed out the ignorance of most people in environmental issues but he was quick to also point out the power of public opinion in government policy decisions. Through constructive criticism these people added a lot of reality to the discussions. Their responses helped to show a number of problems within the thinking of the forestry community. Their responses also helped to show some of the misconceptions about forestry within society. Both of these items are of extreme importance to forestry because first, we must always be re-evaluating our ideas and second, we must understand the misconceptions that exist about forestry and attempt to counteract these misconceptions through education. In an age of environmental concern and public relations this is essential.

Other events of note were the Field Tours. I went on the "Humans, Wildlife, Vegetation, and Fire Interaction in Banff National Park" tour. This tour was run by a number of the Park's staff and its purpose was to show the management efforts within Banff National Park. Banff National Park has a number of challenging management issues that are very much unique including the highest numbers in Canada, the Trans Canada Highway, the Railway and substantial permanent human populations. The Montane ecoregions in Banff National Park have undergone significant changes in forest struc- ture and animal populations over the past 150 years. The Park staff explained to us their past and current attempts to restore balance to the region including prescribed burns, the reintroduction of wolves and the construction of wildlife corridors. They were very frank in expressing their failures and successes. I was struck by the complexity of their problems. On the other hand I was impressed by the great efforts and expenses they have gone through to find a solution. What stands out in my mind from the conference is how it has broadened my view of forestry. Through conversations with practicing foresters and many really interesting lectures I was able to better ascertain the current scope of forestry. Through conversations with retired foresters and Peter Murphy's entertaining lecture on the history of Canadian forestry I have learned about where we have been. And what is always most important to do I have seen some visions of where we may be going. No course that can be taught can do all that. The theme of the conference really does sum it up.

Looking back it was a great week. I met a lot of great people, I ate a lot of good food, I saw a beautiful place and I learned a lot about forestry. I wish I could remember every thing that was discussed and lectured on but I can't. What I do know is that my view of forestry has been broadened and that I am better equipped to chose the path of my studies here at UNB. Once again a most sincere thanks to UNB and CIF/IFC.

Seth Caine

\section{Trip to Chile}

Each year, the Faculty of Forestry and Environmental Management at the University of New Brunswick offers a directed regional studies course, focusing on the social, cultural, historical and biological factors influencing forest management practices employed in a certain region of the world. Previous successful ventures include the Czech Republic, Germany, South Eastern and Central US.

This year, we are focussing our studies on forestry practices in Chile. A two-week trip is planned for 17 students, 8 members of faculty and 2 industry representatives. We will be visiting Chile the first two weeks of March, 2000. Please see our website for more program information http://www.unb.ca/ standint/asdm/chile.html.

The group is looking for sponsors to help pay for this trip, and is hoping that Canadian companies will lend their support. We greatly appreciate the support recieved so far from our sponsors:

- Bowater Maritimes

- JD Irving Ltd.

- Kingsclear First Nation, Partners in Forest Industry, Bob Atwin, Chief and Band Council

- Monsanto Canada

- Smurfit Stone Container, New Brunswick

- Western Forest Products

A word of thanks also goes out to our friends at:

- The Canadian Institute of Forestry

- New Brunswick Forest Products

- UNB faculty of forestry and environmental management

- UNB Woodsman team

And to our hosts in Chile:

- Dan Hermosilla, KBM Forestry, Chile

- Bertram Husch, Infora Estudios Forestry Consultants

Please look for our trip summary, and hopefuly some photos in the next issue of The Forestry Chonicle.

Dirk Nielsen
$5^{\text {th }}$ year Forest Engineering
University of New Brunswick

International
Model Forest Network
Secretariat

